\title{
26. \\ GROBNI SPOMENICI \\ IZ SJEVEROZAPADNE HRVATSKE \\ U SVJETLU ODNOSA RIMSKE ANTIKE \\ PREMA SMRTI
}

\section{Branka Migotti}

UDK: 904:726.821“652“

Izvorni znanstveni članak

Sažetak: Rimska civilizacija bila je opsjednuta čuvanjem uspomene kao zaloga svojevrsnog vječnog života, toliko da je dužnost njegovanja uspomene na mrtve podigla na razinu zakonske obveze. Rimski epitafi, koji se kreću od lapidarnih fraza s osnovnim podacima o pokojnicima i ožalošćenima pa sve do dugačkih pjesama literarne vrijednosti i psihološkofilozofskih aspiracija, pružaju različite podatke o društvenom položaju, materijalnim mogućnostima i religijskim sklonostima stanovnika Carstva. Ipak, takva saznanja do punog izražaja dolaze tek na spomenicima koji združuju riječ i sliku, odnosno nadgrobni natpis i portrete pokojnika praćene različitim simboličnim prizorima i motivima. Njihovo gonetanje, međutim, nerijetko zahtijeva prodiranje u dubinske slojeve slike i čitanje između redaka. Rimsko društvo podiglo je općeljudsko poštovanje prema smrti na razinu dopuštene obmane u kojoj su ljudi bili skloni ne prikazivati se na grobnim spomenicima u stvarnom društvenom položaju, već u priželjkivanom, primjerice, u odjeći koja im nije bila statusno propisana. U ovome se prilogu različiti aspekti (samo)predstavljanja u smrti u razdoblju rimske antike ilustriraju primjerima izabranih grobnih spomenika iz sjeverozapadne Hrvatske. ${ }^{1}$

Ključne riječi: rimska civilizacija, smrt, epitaf, grobni spomenici, Sisak (Siscia), Ščitarjevo (Andautonia)

\section{ODNOS ČOVJEKA RIMSKE ANTIKE PREMA SMRTI}

rema rimskome zakonu, grob je bio sveto mjesto (locus religiosus). ${ }^{2}$ To je podrazumijevalo dvostruku zaštitu pokojnika: zabranu bilo kakvog skrnavljenja vječnog doma (domus aeterna) te brigu za njegovo materijalno održavanje i redovito odvijanje grobnih obreda

1 Zahvaljujem nepoznatom recenzentu/recenzentici na trudu uloženom u otkrivanje slabosti rukopisa, a osobito na uputama za njihovo otklanjanje, što je vidljivo poboljšalo ovaj prilog.

2 Henner von Hesberg, „Planung und Ausgestaltung der Nekropolen Roms im 2. Jh. n. Chr.", Römische Gräberstrassen. Selbstdarstellung - Status - Standard (ur. Henner von Hesberg i Paul Zanker), München 1987., 58; Maureen Carroll, Spirits of the Dead. Roman Funerary Commemoration in Western Europe, Oxford 2006., 4. 
jer se zaborav smatrao najtežim oblikom smrti. Odredba Justinijanova zakonika (Dig., XI, 7, 2, 6), temeljena na predlošku starorimskog prava, kaže: Monumentum est, quod memoriae servandae gratia extat („Spomenik postoji da bi čuvao uspomenu“). ${ }^{3}$ Ona dobro oslikava opsjednutost Rimljana čuvanjem uspomene na mrtve kao zalogom trajanja prekogrobnog života, u smislu da čovjek živi dok živi uspomena na njega. Istina je da je takav odnos opće, takoreći spontano duhovno nasljeđe čovjeka na višoj razini kulture i civilizacije, ali samo su ga Rimljani formalizirali na zakonski obvezujući način. Nije stoga čudo da su se grobovi često podizali, uređivali i održavali već za života budućih pokojnika. Sličan pristup primjećuje se i u odnosu prema groblju kao materijalno-prostornoj sastavnici rimskih naselja, prije svega gradskih. Zakonsko odvajanje groblja od naseljenog mjesta rimska je civilizacija naslijedila od grčko-helenističke, ali je taj postupak prilagodila i razvila na osobit način koji je u pogledu općeg civilizacijsko-antropološkog doživljaja smrti izdvaja od ostalih povijesnih društava. Poznato je da su rimska gradska groblja bila poredana uz ceste extra muros i da su se povećanjem broja pokojnika razvijala u usporednim redovima manje ili više udaljenima od ceste. ${ }^{4}$ Međutim, želja za prestižnim pokopavanjem neposredno uz cestu u velikim je gradovima protegnula groblja kilometrima izvan gradskih zidina. Pritom se grobovi nisu susretali samo sa sakralnim sadržajima kao i u grčko-helenističkoj kulturi, već i s posve svjetovnim i s gledišta suvremenog poštovanja prema smrti nepriličnim zdanjima poput otmjenih vila, gospodarskih imanja s radionicama, pa čak i javnih kupališta, gostionica i prenoćišta. ${ }^{5}$ I sve to radi mentaliteta prestiža i želje za komunikacijom jer jedino su se epitafima grobova neposredno uz cestu pokojnici mogli obraćati svim prolaznicima, a ne samo užem krugu obitelji i prijatelja te $s$ mnogim ljudima podijeliti misli o prolaznosti života i podgrijavati nadu u svojevrsnu virtualnu besmrtnost, različitu od one stvarne, kakvu će propovijedati kršćanstvo. Tek će kršćanski svjetonazor u okviru rimske antike prekinuti opisan prostorni suživot živih i mrtvih, okupljajući groblja oko crkava i razdvajajući ih od svjetovnih sadržaja čak i onda kad ih je za duga stoljeća, praktički sve do suvremenog razdoblja, uključila u neposredno gradsko tkivo.

Rimski epitafi, koji se kreću od lapidarnih fraza s osnovnim podacima o pokojnicima i ožalošćenima pa do dugačkih pjesama literarne vrijednosti i psihološko-filozofskih aspiracija, pružaju različite podatke o društvenom položaju, materijalnim mogućnostima i religijskim sklonostima stanovnika Rimskog Carstva. Ipak, takva saznanja do punog izražaja dolaze tek na spomenicima koji združuju riječ i sliku, odnosno nadgrobni natpis i reljefne portrete pokojnika praćene različitim simboličnim prizorima i motivima. Njihovo gonetanje, međutim, nerijetko zahtijeva prodiranje u dubinske slojeve slike i čitanje između redaka. Rimljani su naime, osobito oni s netom stečenim rimskim građanstvom, bili skloni

3 Jocelyn Toynbee, Death and Burial in the Roman World, Baltimore - London 1996., 61-62, 75-77; M. CArroll, Spirits of the Dead, 1, 19, 30, 185-186; Jane Fejfer, Roman Portraits in Context, Berlin - New York 2008., 105-106; Stine BIRK, Depicting the Dead. Self-Representation and Commemoration on Roman Sarcophagi with Portraits, Aarhus 2013., 9 .

4 H. von Hesberg, „Planung und Ausgestaltung der Nekropolen Roms im 2. Jh. n. Chr.“, 50-51; J. Fejfer, Roman Portraits in Context, 109.

5 Nicholas Purcell, „Tomb and Suburb“, Römische Gräberstrassen, 29-33; M. Carroll, Spirits of the Dead, 1, 3, 64. 
predstavljati se na grobnim spomenicima ne u stvarnom, nego u priželjkivanom društvenom položaju, primjerice, u odjeći koja im nije bila statusno propisana. ${ }^{6}$

Osim navedenog, posve svjetovnog razloga manipuliranja društvenim položajem, cjelovito tumačenje rimskih grobnih spomenika usložnjavaju dva međusobno povezana vida grobne kulture, oba iz prostora duhovnosti i religije. Prvi se odnosi na zamišljanje i razumijevanje besmrtnosti, a drugi na religijsku simboliku likovnih prizora na spomenicima. Saznanja, ili radije naslućivanja o tome kako su Rimljani zamišljali besmrtnost, oslanjaju se na pisane podatke te na grobne spomenike i drugu arheološku građu. Budući da ti izvori pružaju vrlo oskudne, a opet raznovrsne uvide - jer se odnose na ljude u drugačijim prostornim, vremenskim, društvenim i kulturnim dimenzijama - naše razumijevanje ove teme ostaje nepotpuno, a saznanja je gotovo nemoguće smisleno objediniti na malom prostoru. Za ilustraciju donosim nekoliko primjera iz rimske literature. Marko Tulije Ciceron (Marcus Tullius Cicero, 1. stoljeće pr. Kr.), rimski pravnik, političar, govornik i pisac, na jednom mjestu u svojim Raspravama u Tuskulu (Cic. Tusc. 1, 27) navodi kako su Rimljani oduvijek gajili različite predodžbe o nastavku života, zamišljajući smrt više kao preobrazbu i seljenje, ali ne na isto mjesto: kao besmrtnici, slavni muževi i žene, odlazili su na nebo, dok su smrtnici ostajali na zemlji. Iz šume literarne i arheološke građe o temi smrti naslućuje se vjera Rimljana u postojanje nekakvog oblika života nakon smrti, ali su predodžbe o njemu bile mutne; pokojnike su neki zamišljali poput sjena bez osobnosti, dok su ih drugi vidjeli kao bića koja su barem dijelom zadržala svoj oblik i svijest živih ljudi. ${ }^{8}$ Svijet mrtvih pritom se zamišljao na različitim mjestima.

U poetskoj viziji nasljedovala se zamršena trodioba Podzemlja prema grčkom obrascu, s odvojenim mjestima za krivce koji ispaštaju, potom za prerano umrle te, naposljetku, za pravedne i zaslužne koji uživaju na Elizejskim poljanama, ili u svemirskim prostranstvima, ili, pak, na Otocima blaženih onkraj Oceana. ${ }^{9}$ Kao ilustraciju različitih viđenja o posmrtnom životu evo dvaju primjera, čiji su autori, premda vremenski udaljeni tek jedno stoljeće, bili na dvjema miljama udaljenim svjetonazorskim polovima. Prvi je Trimalhion, lik iz romana Satyricon pisca Petronija (Gaius Petronius Arbiter, 1. stoljeće), razmetljiv i nadmen skorojević, bivši rob koji, opisujući svoj zamišljen raskošan grob, izjavljuje kako će mu ta građevina osigurati život nakon smrti jer da je besmisleno imati lijepu kuću za života, a ne brinuti se za onu u kojoj ćeš živjeti znatno dulje (Satyricon 71, 7). ${ }^{10} \mathrm{Na}$ drugom kraju spek-

$6 \quad$ Najizrazitiji primjer jest takva „zlouporaba“ toge, kao statusne odjeće rimskog građanina i stoga nedostupne ljudima bez građanskog prava. Usp. Hans Rupprecht Goette, Studien zu römischen Togadarstellungen, Mainz am Rhein 1989., 2 i dalje; Shelly STone, „The Toga: From National to Ceremonial Costume“, The World of Roman Costume (ur. Judith Lynn Sebesta i Larisa Bonfante), Madison - London 1994., 17; J. Fejfer, Roman Portraits in Context, 33 i dalje.

7 Cinzia Vismara, „L’apport des textes antiques“, Incinérations et inhumations dans l'Occident romain aux trois premiers siècles de notre ère (ur. Michel Vidal), Toulouse i992., inz.

8 J. Toynbee, Death and Burial in the Roman World, 35-36; Jacopo Ortalli, „Simbolo e ornato nei monumenti sepolcrali romani: il caso aquileiese", Aquileia dalle origini alla costituzione del ducato longobardo. Topografia, urbanistica, edilizia pubblica (ur. Giuseppe Cuscito i Monika Verzár Bass), Trieste 2004., 275-278; M. Carroll, Spirits of the Dead, 3-4; J. Fejfer, Roman Portraits in Context, 105; S. Birk, Depicting the Dead, 51-54.

9 J. Toynbee, Death and Burial in the Roman World, 36-39.

10 Petronije Arbiter, Satirikon ili vragolaste pripovijesti (prir. Antun Branko Kalinić), Zagreb 1986., 103; N. PurCELL, „Tomb and Suburb“, 25. 
tra razmišljanja o vječnosti stoji rimski car Marko Aurelije (121. - 180.). U filozofskom

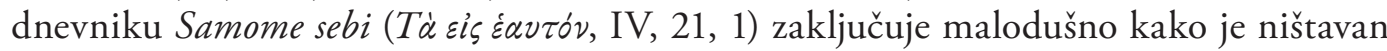
ljudski život jer nakon smrti tijela duše lebde u svemiru, koji će ih nakon nekog vremena progutati kako bi napravio mjesta za nove duše. ${ }^{11}$ Cara filozofa očito se nisu dojmile soteriološke zamisli orijentalnih misterija poput onih Demetre i Perzefone, Kibele (Velika majka bogova/Magna Mater Deorum), Izide, Orfeja, Mitre i Dioniza, koje su upravo za njegova života zadobile osobito snažan utjecaj na religijski život Carstva. Ti su misteriji mitovima o smrti i ponovnom rađanju bogova dotaknuli nadu u cikličku obnovu života i za sljedbenike, približivši se tako kršćanskoj dogmi vječnog života. ${ }^{12}$

O drugom elementu koji utječe na ukupno tumačenje grobnog spomenika, religijskoj simbolici prikazanih motiva i prizora, napisane su stranice i stranice rasprava i osvrta, koje je moguće svesti na jednu jedinu dvojbu: ukras ili simbolika. Rijetko bi tko posumnjao u to da likovi bogova i mitološki prizori nose posve određenu simboliku vjerovanja, strahova, nada i predrasuda vezanih uz odnos čovjeka rimske antike prema svakodnevici, prošlosti i budućnosti, vrlini i mani, životu i smrti, religiji i svemu što je ljudska misao dotaknula. ${ }^{13}$ Nasuprot tome, pojedinačni motivi životinja i biljaka, posebno potonjih, često se svode na puki ukras bez simboličke uloge, što je previše pojednostavnjeno gledanje. Budući da je grobna ikonografija u osnovi duboko religijski uvjetovana, s obzirom na to da je i sâm grob locus religiosus, nema dvojbe da je u temeljnoj zamisli svaka dekoracija nosila izvjesnu, pa makar i višeznačnu, religijsku simboliku. ${ }^{14}$ Ta simbolika nije nestala zato što je vjerojatno bilo ljudi koji je s vremenom više nisu razumjeli pa su, birajući motive za grobni spomenik, vidjeli u njima samo ukras.

\section{Spomenici}

Odnos religijske i filozofske simbolike prizora pri tumačenju rimskih grobnih spomenika zapravo i nije moguće posve izbjeći jer su ta dva aspekta nerijetko (posredno ili neposredno) povezana s društvenim položajem budućeg pokojnika i njegovom zamisli o tome kako se želio predstaviti na spomeniku. $U$ ovome se razmatranju naglasak stavlja na aspekte života u okviru rimske civilizacije u sjeverozapadnoj Hrvatskoj, predočene grobnim spomenicima razdijeljenim u manje tematske skupine. $S$ obzirom na takav pristup, u razmatranjima (samo)predstavljanja pokojnika daje se prednost njihovu društvenom položaju i statusu u kontekstu provincijalno-rimske kulture, s religijskim aspektima u drugom planu.

11 C. Vismara, „L'apport des textes antiques“, 128-129.

12 Robert Turcan, The Cults of the Roman Empire, Oxford - Cambridge, MA 1996.; J. OrTalli, „Simbolo e ornato nei monumenti sepolcrali romani: il caso aquileiese“, 275-278.

13 J. Fejfer, Roman Portraits in Context, 133-135; S. Birk, Depicting the Dead, 94-107; Guntram KocH - Hellmut Sichtermann, Römische Sarkophage, München 1982., 614-617.

14 G. Koch - H. Sichtermann, Römische Sarkophage, 601; Branka Migotti, „Ranokršćanski grobni nalaz iz Velikih Bastaja kod Daruvara“, Vjesnik Arheološkog muzeja u Zagrebu, 28-29/1995. - 1996., 143; J. OrTalli, „Simbolo e ornato nei monumenti sepolcrali romani: il caso aquileiese“, 267-279. 


\section{1. Veteran}

Mramorna stela veterana Tita Flavija Atebodua, Aterigova sina (Sl. 1.), nađena je 1992. u selu Odri kod Zagreba, na području rimskog grada Andautonije. Arheološki kontekst upućuje na to da je veteran bio pokopan na svome imanju u ranom 2. stoljeću, a njegova raskošna stela jedan je od najljepših rimskih nadgrobnih spomenika sjeverne Hrvatske. ${ }^{15} \mathrm{Na}$ bočnim stranama zabata leže lavovi s ovnujskim glavama u šapama, a u njegovu je središtu glava Meduze s krilcima na tjemenu i zmijama zavezanima pod bradom; zmijska tijela vijugaju uvis uz Meduzine obraze, a sa svake strane vrebaju ih ptice grabljivice. Friz pod zabatom i stupovi uz natpisno polje ukrašeni su motivima lotosa i palme, a donji dio stele zaprema trodijelni prizor naoružanog konjanika okruženog dvama krilatim erotima, koji tugu iskazuju naopako okrenutom bakljom provučenom kroz vijenac i obrazom naslonjenim na dlan ruke položene na rame. Za razliku od mitoloških likova i simboličkih motiva, jedini stvaran prizor na ovoj steli jest konjanik koji nesumnjivo prikazuje pokojnika, što se dade zaključiti iz epitafa: T(ito) Fl(avio) Aterigis / fll(io) Ateboduo I an(norum) LXXVve[te]r(ano) / emerito coh(ortis) I[I] Va[r](cianorum) / 5 eq(uitatae) cornuclario (!) / praef(ecti) et Crispi[n](ae) / coniug(i) an(norum) $L V$ / et Fl(avio) Augurino nep(oti) / an(norum) V. / ${ }^{10}$ $H$ (eres) f(aciendum) c(uravit). Prijevod glasi: „Nasljednik se pobrinuo da se načini za sedamdesetpetogodišnjeg Tita Flavija Atebodua, Aterigova sina, umirovljenog veterana Druge konjaničke kohorte Varcijanâ i pomoćnika zapovjednika kohorte, te za njegovu pedesetpetogodišnju suprugu Krispinu i petogodišnjeg unuka Flavija Augurina."

Prikaz konjanika na donjem dijelu stele nije portret u pravom smislu, uobičajen za rimsku grobnu portretistiku, u kojoj se pokojnici najčešće prikazuju u obliku poprsja, a rjeđe čitavih likova, ali nije ni posve općenit motiv. Konjanik je svojevrstan generički prikaz vlasnika stele, nekadašnjeg vojnika konjaničke jedinice, čiji nadgrobni spomenik i svojom raskoši, ali i izborom prizora odražava ponos domaćeg čovjeka koji je ostvario uspješnu vojničku karijeru i postao istinski Rimljanin. Njegov kognomen (cognomen) Atebod (Ateboduus)

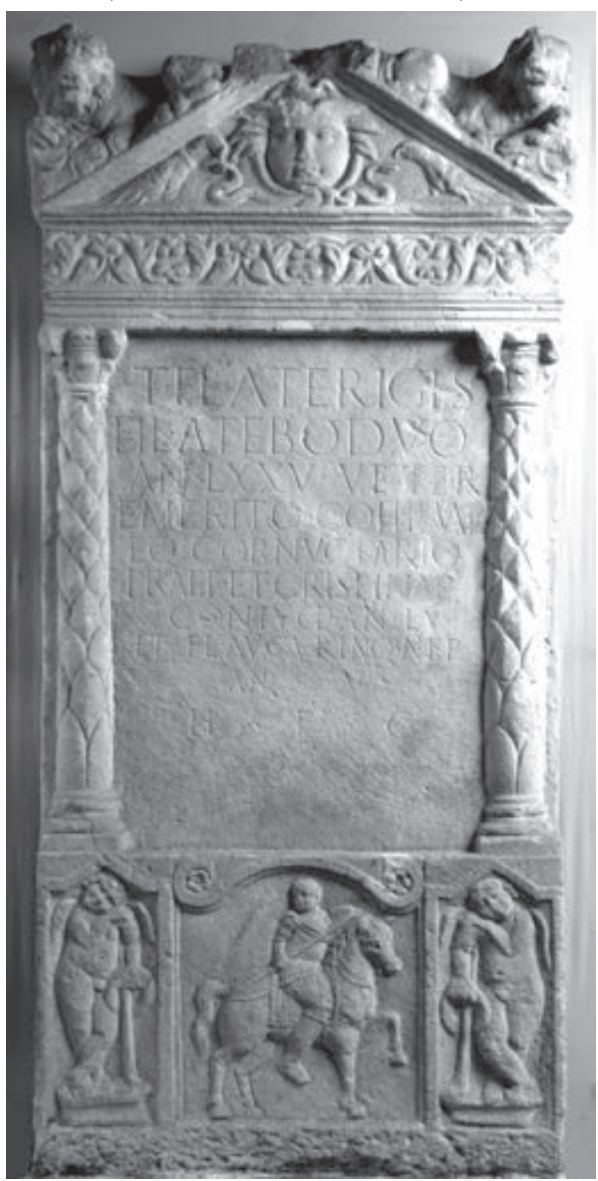

Sl. 1. Stela Tita Flavija Ateboda (2. stoljeće), Odra kod Zagreba (Arheološki muzej u Zagrebu)

15 Ante Rendić-MiočEvić, „The Marble Funerary Stele of the Cohors II Varcianorum Equitata's Veteran, Titus Flavius Ateboduus from the Odra Village near Zagreb“, Sepulkralna skulptura zapadnog Ilirika i susjednih oblasti u doba Rimskog Carstva (ur. Nenad Cambi i Guntram Koch), Split 2013., 343-381; Année épigraphique 2013., 1206. 
svjedoči da je posrijedi pripadnik domaćeg plemena Varcijanâ, a ne izvorni Rimljanin, o čemu govori i očevo mu ime Aterig (Aterix). Dok otac nikad nije dobio rimsko građansko pravo, što proizlazi iz nedostatka trodijelne rimske imenske formule (tria nomina), sinovljevi praenomen i nomen upućuju na to da je to pravo dobio za vrijeme careva Flavijevaca (69. - 96.), pri čemu mu je izvorno ime Atebod, u latiniziranom obliku Ateboduus, dospjelo na posljednje mjesto, kao cognomen. Prema tome, Atebod se bio prijavio u kohortu svojih sunarodnjaka kao panonski Kelt bez građanskog prava, takozvani peregrin, da bi u službi napredovao do mjesta kornikularija (cornicularius) - pomoćnika (svojevrsnog tajnika) zapovjednika jedinice, a vojnički staž završio stjecanjem građanskog prava. Ime njegove dvadeset godina mlađe supruge Krispine (Crispina) rimsko je i ne otkriva njezino etničko podrijetlo.

Atebod je u veteranskoj mirovini poživio dugo, a sudeći prema grobnom spomeniku, nije ni oskudijevao materijalno; mramor je na područje Andautonije trebalo uvoziti iz Petovione (Poetovio, Ptuj u Sloveniji), odnosno s planine Pohorja u blizini toga grada ili iz još udaljenijih noričkih gradova. Ipak, Atebodov epitaf otkriva sudbinu koja se ne bi mogla nazvati obrascem obiteljske sreće. Budući da je grob dao načiniti neimenovan nasljednik, očito ne član obitelji, jasno je da je Atebod dijete ili djecu izgubio prije negoli unuka, a potom i unuka u dječjoj dobi, ostavši bez nasljednika loze i onoga tko je trebao uživati stečenu obiteljsku čast i imetak. Mali Flavije Augurin imao je građansko pravo, o čemu svjedoči dvočlana rimska imenska formula, a njegovo osobno ime više ni u tragovima ne odaje keltsko-panonsko podrijetlo. Tko zna je li ta mala obitelj u svome krugu komunicirala na jeziku Varcijana ili na latinskome.

\section{2. Glumac i stogodišnjak}

Prosječan životni vijek u Rimskome Carstvu procjenjuje se na 20 - 30 godina, što je izrazito niska stopa prema današnjim mjerilima. Mnogi su pretpostavljeni razlozi tome: velika smrtnost novorođenčadi i djece, smrtnost žena pri porođaju i muškaraca u ratovima te svih zajedno zbog nepovoljnih uvjeta života koji je, unatoč razmjerno visokoj razini rimske medicine, bio osobito ugrožen raznim epidemijama, osobito u zagušljivim malaričnim riječnim dolinama i prenatrpanim zagađenim gradovima. ${ }^{16}$ Zbog takve procjene životne dobi stanovnika Carstva podatak o stogodišnjaku na nadgrobnom natpisu iznenadit će neupućene, ali bez razloga: dugovječnost u to doba zapravo nije bila rijetkost. Ono što je zanimljivo u ovom kontekstu jest podatak da su provincije Norik i Panonija spadale među one u kojima je na epitafima zabilježeno osobito mnogo stogodišnjaka. ${ }^{17}$

Jedan od dvojice stogodišnjaka spomenutih u epitafima s razmatranog prostora bio je glumac, što daje prigodu zaviriti u svijet koji je oduvijek očaravao suvremenike, često izazivajući podijeljene osjećaje. Mramorna nadgrobna ploča (Sl. 2.) s epitafom stogodišnjaka

$\overline{16}$ M. Carroll, Spirits of the Dead, 175; Marjeta ŠAšEL Kos, „Centenarians in the Emona area and the adjacent Norican and Pannonian regions", Misurare il tempo, misurare lo spazio (ur. Maria Gabriella Angeli Bertinelli i Angela Donati), Faenza 2006., 179-183.

17 Isto, 188-195. 
Leburne iz 4. stoljeća nađena je 1823. u Sisku na prostoru zapadne siscijske nekropole. Vlasnik vinograda u kojemu je iskopana, trgovac Paulus Bitroff, dao ju je otpremiti u Mađarski narodni muzej u Budimpešti, gdje se i danas nalazi. Teatralno osebujan epitaf glasi: $D($ is $)$ M(anibus) / positus est hic Leburna / magister mimariorum / [q] ui vicxit(!) annos plus / [m] inus centum / [al]iquoties mortuus / [sum] set sic nunquam / [opto v] os ad superos bene / [va] ler\{a\}e. U prijevodu: „Bogovima Manima. Ovdje leži vođa glumaca Leburna, koji je živio stotinjak godina. Umro sam mnogo puta, ali nikada ovako. Vama koji ste još živi želim da ste dobro i zdravo." ${ }^{18}$

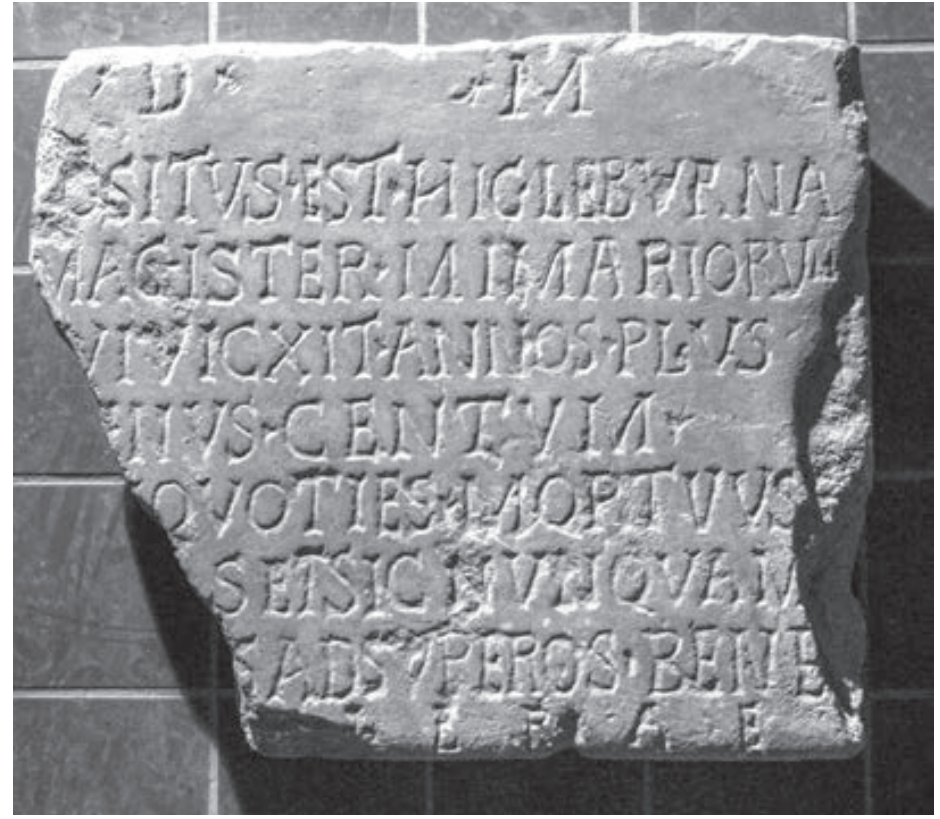

Sl. 2. Nadgrobna ploča Leburne (4. stoljeće), Sisak (Mađarski narodni muzej, Budimpešta)

Natpis sadrži dva dijela, jedan koji treba pripisati postavljaču spomenika i drugi koji izgovara sâm pokojnik, pri čemu osobitu pozornost privlače dva detalja. Prvi je navođenje pokojnikove dobi izrazom manje-više (plus minus). Godine navedene u epitafima često su se zaokruživale, ali se pretpostavlja da je to bilo prije zbog neznanja negoli zbog nemara. Međutim, u kasnijem razdoblju, počevši od 3. stoljeća, izraz plus minus postao je uobičajen detalj grobne epigrafije pa je moguće povezati ga sopćim duhovnim raspoloženjem kasne antike. U tom su se razdoblju, naime, mnoga pravila, pa i zakoni „razvodnili“ drugačijim tumačenjima i/ili praksama, posebno u provincijama udaljenima od Rima i Italije i prostorno i svjetonazorski. Gotovo da bismo kasnoantičko razdoblje (3./4. - 7. stoljeće) u okviru klasične antike smjeli usporediti sa suvremenom postmodernom i njezinom sveopćom eklektičnošću i relativizacijom duhovnih i moralnih vrijednosti te svjetonazorskih obrazaca. U takvom kontekstu možda je zaista postalo nevažno je li netko u času smrti imao par godina manje ili više. $S$ druge strane, neobvezatnost izraza plus minus u danom kontekstu mogla bi se povezati is duhovitošću rečenice kojom se pokojnik obraća prolaznicima, svojoj 
novoj publici u zagrobnom životu, izjavljujući da je „umro mnogo puta, ali nikada ovako“. Premda je tu rečenicu mogao smisliti i postavljač natpisa, čini se da ona ipak odražava duh glumca Leburne pa je veoma vjerojatno da ju je smislio on sâm, i to upravo za potrebe svog posljednjeg „nastupa“. Naime, navedena rečenica odnosi se na pokojnikovo zanimanje u doslovnom smislu, ali i kao ilustracija humora svojstvenog tom zanimanju, odnosno mimu (mimus), kazališnoj grani u kojoj je nastupao Leburna. ${ }^{19} \mathrm{Za}$ razliku od komedije ranijih razdoblja i zahtjevnije suvremene pantomime, mimičari su karikirali i parodirali svakodnevne „prizemne“ životne sadržaje i likove, nerijetko i na opscen način, iznimno s natruhama ironije, satire i kritike, ali zato s glavnom namjerom da nasmiju i zabave. ${ }^{20}$ Dva su moguća izvora Leburnine šaljive primjedbe iz epitafa. Jedan je taj što su se mimi prikazivali i u okviru pogrebnih povorki u kojima je glumac burlesknim načinom oponašao pokojnikov život. ${ }^{21}$ Drugi je, moguće, u samim sadržajima mima, nadahnutima svakodnevnim zgodama i spletkama, uključujući i lažne smrti. Prema tome, Leburna je u raznim kazališnim okolnostima uistinu umro mnogo puta.

Društveni položaj i status glumaca najbolje pokazuju pragmatičnu dvoličnost rimskog društva. U očima su zakona glumci bili obespravljeni položajem otprilike na razini radnika, robova i gladijatora pa su najčešće i dolazili iz redova robova i oslobođenika. Glumice su bile gotovo sinonim za prostitutke, a ni glumci nisu bili daleko od takvog glasa, zasluženog razvratnim prizorima u predstavama, koji su bili pretjerani čak i za općenito srozan rimski moral u razdoblju Carstva. S druge strane, pojedini glumci postali su ljubimci publike i pojedinaca iz viših slojeva. I u kasnoj antici, kada je živio Leburna, legalan položaj glumaca ostao je nepromijenjen, i dalje istodobno prezren i uzdizan. Na moralnu upitnost glumaca osobito je prijekim okom gledala Crkva. ${ }^{22}$ Mnoge je uspjela obratiti na kršćanstvo i odvratiti od glumačkog poziva, ali ne i Leburnu, premda je živio u gradu koji je bio biskupija. U Leburninu epitafu tako nema ni traga kršćanskog svjetonazora. Čini se da se u opisanom društvenom kontekstu naš glumac sasvim dobro snašao i duhovno i materijalno, o čemu svjedoče različiti detalji njegova života, zabilježeni u epitafu: dugovječnost, živ smisao za humor, titula magistra glumaca (magister mimariorum) i, konačno, mramorna nadgrobna ploča šaljiva sadržaja.

\section{3. Robovi}

Pojam roba u modernoj svijesti izaziva predodžbe o teškom životu i najcrnjoj ljudskoj sudbini. Jednim dijelom to svakako vrijedi i za rimsku civilizaciju jer su robovima zakonom bila ne samo uskraćena građanska prava, nego su se smatrali imovinom gospodara

\footnotetext{
19 Mimom se nazivala i kazališna predstava i glumac koji je u njoj glumio, a naslov magister mimariorum svjedoči da je Leburna bio glavni glumac, a moguće i vlasnik glumačke družine. Usp. Costas Panayotakis, Theatrum Arbitri. Theatrical Elemets in the Satyrica of Petronius, Leiden 1995., XVII.

20 Giusto Traina, „Lycoris the mime“, Roman Women (ur. Augusto Fraschetti), Chicago - London 2001., 85-88; Richard Miles, „Actors and acting“, Late Antiquity. A Guide to the Postclassical World (ur. Glen Warren Bowersock, Peter Brown i Oleg Grabar), Cambridge, MA - London 1999., 276-277; Richard Lim, „Theater“, Late Antiquity, 719-721.

21 Geoffrey Sumi, „Impersonating the Dead: Mimes at Roman Funerals“, The American Journal of Philology, $123 / 2002$. br. 4, 559-585.

22 G. Traina, „Lycoris the mime“, 84-85; R. Miles, „Actors and acting“, 276-277; R. Lim, „Theater“, 720.
} 
na razini s nekretninama, životinjama ili stvarima. S druge strane, način na koji su rimski građani doživljavali robove čini potonje najintrigantnijom društvenom skupinom rimske statusne ljestvice jer se njihova zakonska obespravljenost u svakodnevici ostvarivala u golemom rasponu različitih mogućnosti, a i psihološki odnos ostatka društva prema njima bio je prilično nijansiran. Dok se jedne zlostavljalo u ponižavajućim uvjetima, drugi su imali mogućnost samostalno voditi vlasnikove poslove i pritom zaraditi dovoljno za otkup iz ropstva, dok su oni najsretniji ostvarivali prijateljstvo i gotovo rodbinsku prisnost obitelji svojih gospodara. Slično kao u glumaca, istodobno preziranih i hvaljenih, stvarni položaj robova odražavao je proturječnost rimskog zakonodavstva utoliko što je sužanj u svakom pogledu mogao nadići ne samo položaj slobodnog čovjeka nego i rimskog građanina. ${ }^{23}$

Jedna od ljepših vapnenačkih stela u lapidariju Arheološkog muzeja u Zagrebu (Sl. 3.) pripadala je robovskoj obitelji iz sredine 2. stoljeća. ${ }^{24}$ Nađena je slučajno 1989 . tijekom komunalnih radova u Donjim Čehima u pred-

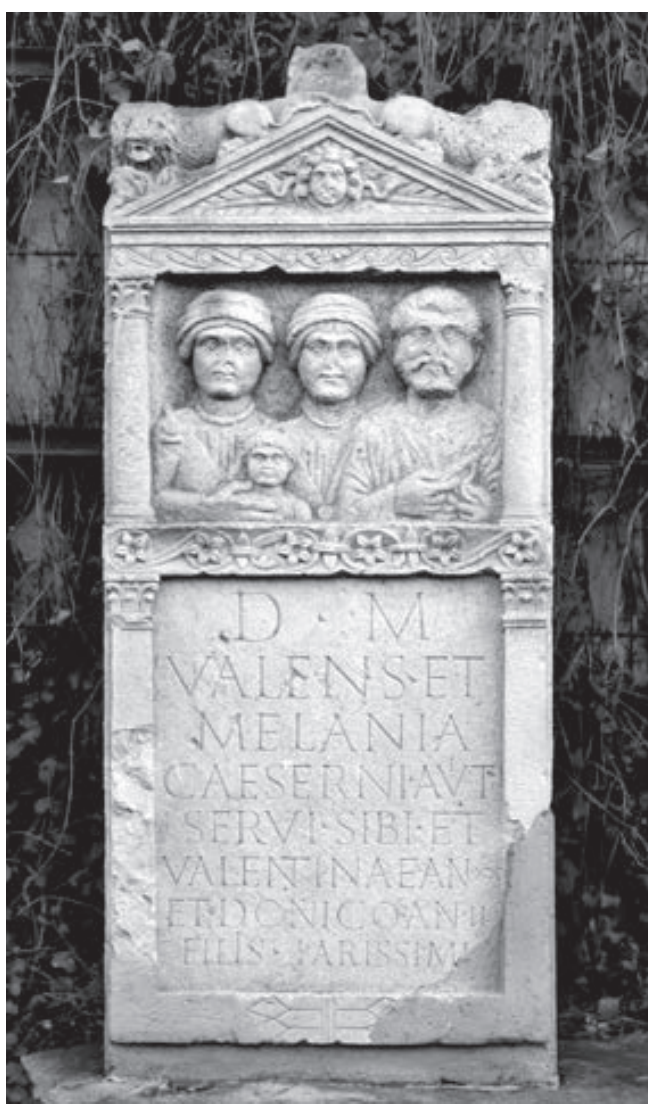

Sl. 3. Stela robovske obitelji (2. stoljeće), Donji Čehi (Arheološki muzej u Zagrebu) građu Zagreba. Premda nedostaje donji dio stele, potpuno su sačuvani i epitaf i portretna niša, a s njima i dobar dio životne priče robovske obitelji kojoj su društvene okolnosti bile naklonjene, ali ih je sudbina osujetila svojim za to vrijeme uobičajenim oružjem - preranim smrtima (mortes immaturae). Epitaf glasi: D(is) M(anibus) / Valens et / Melania / Caeserni Aviti / ${ }^{5}$ servi sibi et / Valentinae an(norum) XX / et Donico an(norum) II / fliis rarissimis. U prijevodu: „Bogovima Manima. Valent i Melanija, robovi Cezernija Avita, sebi i predragoj djeci: dvadesetogodišnjoj Valentini i dvogodišnjem Doniku.“

Bez obzira na pojedine nezgrapnosti u detaljima izvedbe, stela je raskošan, dopadljiv i u cjelini vrsno isklesan spomenik. Na sredini zabata prikazana je Meduzina glava, a na njegovim bočnim stranama leže lavovi s ovnujskim glavama u šapama. Na prvi pogled uočava se samosvijest prikazanih osoba vidljiva u odjeći i portretnim crtama koje oponašaju carske fizionomije i frizure. Na desnoj strani niše prikazan je Valent s frizurom te bradom i brkovima koji oponašaju izgled cara Antonina Pija (138. - 161.), odjeven u tuniku i ogrtač

23 Branka Migotтı, „Nadgrobni spomenik robovske obitelji iz Donjih Čeha kod Zagreba“, Archaeologia Adriatica, 2/2008., br. 2, 453-454; Sandra R. Joshel, Slavery in the Roman World, Cambridge 2010.; Henrik Mouritsen, The Freedmen in the Roman World, Cambridge 2015., 10-36.

24 Année épigraphique 2002., 1125; B. Migotтi, „Nadgrobni spomenik robovske obitelji“. 
(sagum) prikopčan na desnom ramenu okruglom kopčom. To je odjeća rimskog građanina u kakvoj se najčešće portretiraju vojnici ili civilni dužnosnici, ali ne i robovi; u svakodnevnom životu Valent je, prema zakonu, trebao biti odjeven u tuniku ili neku jednostavnu varijantu domaće radne odjeće. ${ }^{25}$ Lijevo do Valenta likovi su njegove žene Melanije i kćeri Valentine, obje prikazane s prevladavajućim domorodačkim detaljima u odjeći, ali i s jasnim naznakama pripadanja rimskom društvu. Njihova domaća odjeća i oprema sastoji se od tunike, ogrtača prikopčanog ili ukrašenog okruglom kopčom na sredini grudi, kape te nakita (ogrlica na objema ženama i narukvica na onoj s lijeve strane). Žena u lijevom kutu morala bi biti Melanija s obzirom na to da desnom rukom grli dječaka, svog sina Donika, prikazanoga u prvom planu između majke i sestre. Jedini detalj kojim dvije žene pokazuju i svoju „rimskost“ (Romanitas) odnosi se na frizure. Ona u sredini, pretpostavljena Melanija, na čelu ima kovrče koje se pojavljuju u carice Faustine Starije, supruge cara Antonina Pija, a poslije i u njezine kćeri Faustine Mlađe, supruge cara Marka Aurelija (161. - 180.). Zanimljivo je da je u obiju žena kosa uz gornji dio obraza počešljana na način noričko-panonskih domorotkinja, različito od frizura dviju spomenutih carica. Prema tome, dvije su ropkinje pažljivo pratile carsku modu češljanja, primjenjujući je tek u detalju koji je trebao pokazati da su u „u tijeku“, dok su njihovi osjećaji bili na strani izražavanja panonskokeltskog podrijetla s pomoću odjeće.

Gornji podaci svjedoče da je ova obitelj imala sreću kad je za vlasnika dobila Cezernija Avita (Caesernius Avitus). On je očito pripadao noričkoj grani elitne akvilejske senatorskoveleposjedničke obitelji Cezernijâ, koja je u 1. i 2. stoljeću rasprostrla mrežu poduzetništva i trgovanja u sjevernoj Italiji, Noriku i Panoniji. Bavljenje trgovinom moglo bi objasniti bič koji u ruci drži Valent na svom grobnom portretu, a koji najvjerojatnije simbolizira putovanje kao njegovu osnovnu djelatnost u službi gospodara Cezernija Avita. Sve u svemu, Valentova obitelj u materijalnom je smislu bila uspješna i zadovoljna svojim položajem jer kako drukčije objasniti činjenicu da nisu marili otkupiti se iz ropstva? Budući da su uvjeti za otkupljivanje, uz dobru volju gospodara, bili navršenih trideset godina i dovoljno zarađenog novca, ${ }^{26} \mathrm{i}$ Valentova zrela dob izražena portretom i podatak o dvadesetogodišnjoj kćeri, a potom vjerojatno i prilično skup grobni spomenik, svjedoče da prepreke stjecanju slobode najvjerojatnije nije bilo. Prema tome, obitelj iz ove priče dobar je primjer zadovoljnog robovanja u rimskom društvu.

\section{4. „Ženski svijet“ - rimska žena između patrijarhata i samosvijesti}

Bez obzira na literarne nijanse kojima se u rimskoj antici opisivala ženska narav i njezina ulogu u društvu, zakonodavstvo joj je namijenilo podređenu ulogu kao biću uvelike ovisnom u muškom skrbništvu i lišenome političkih prava. ${ }^{27}$ Istina, položaj žene ovisio je

\footnotetext{
25 Bez obzira na dvojbenost pisanih izvora i arheoloških spomenika te na suprotstavljena mišljenja o tome, čini se da su tunika i ogrtač bez kovinske fibule bili osnovna odjeća roba, a da su sve ostale varijante predstavljale stvarno pretjerivanje ili takvo predstavljanje na spomenicima. Usp. S. R. JosheL, Slavery in the Roman World, 132-136.

26 H. Mouritsen, The Freedmen in the Roman World, 34-35, 159-180.

27 Augusto Fraschetti, „Introduction“, Roman Women, 3-4; Branka Migotтi, „The Social/Gender Context of the Sarcophagus of a togata clarissima femina from Siscia (Pannonia Superior)“, Archaeologia Bulgarica, 11/2007., br. 1, 61-79; J. Fejfer, Roman Portraits in Context, 345-346.
} 
o njezinu društvenom statusu is vremenom mijenjao se nabolje pa se ugledna Rimljanka mogla istaknuti i ostaviti povijesni trag. Ipak, mogla je to učiniti samo dvama načinima, obama podjednako ovisnim o muškarcima iz kruga obitelji ili prijatelja: podržavati ih „iz sjene" ili, pak, javnim postupcima, budeći u sebi takozvane muške osobine i preobražavajući se u „muževnu ženu“ (mulier virilis). Možda su upravo potonje okolnosti urodile neuobičajenim likom žene na jednom mramornom sarkofagu iz Siska (Sl. 4.).

Taj sarkofag, jedinstven po mnogim detaljima natpisa i reljefnih prizora, nađen je slučajno 1882. na jugoistočnoj siscijskoj nekropoli, a potječe iz druge polovine 3. stoljeća. ${ }^{28}$ Epitaf glasi: [D(is) M(anibus) ?] / Romania N(a)evia clari /ssima femina viva / fecit sibi memoriam / ${ }_{5}^{5}$ pr(a)ecurrentibus Cletio / Romuliano et Aur(elio) / Calemero. Zbog oštećenja površine kamena nije sigurno je li epitaf počinjao uobičajenim zazivom Dis Manibus, ali uz pretpostavku da jest, prijevod glasi: „Duhovima umrlih. Romanija Nevija, clarissima femina, dala je za života sebi načiniti memoriju nakon što su je pretekli Kletije Romulijan i Aurelije Kalemer." Prozni grobni natpisi u pravilu su ujednačeni u izboru riječi i fraza; ako su dobro sačuvani, velik broj njih čita se i razumije bez poteškoća. To se, međutim, ne odnosi na ovaj primjer pa je ponuđeni prijevod jedan od dvaju mogućih, s time da su oba podjednako zagonetna, ostavljajući lik vlasnice sarkofaga i njezin postupak u vezi s pokopom tek djelomično rasvijetljenim. Sintagma clarissima femina (veoma ugledna žena; doslovce: najsjajnija žena) službena je senatorska titula stečena obiteljskim nasljeđem od oca ili muža. To znači da je pokojnica pripadala senatorima, najvišem sloju rimskog društva, na hijerarhijskoj ljestvici smještenom neposredno ispod carske obitelji. ${ }^{29}$

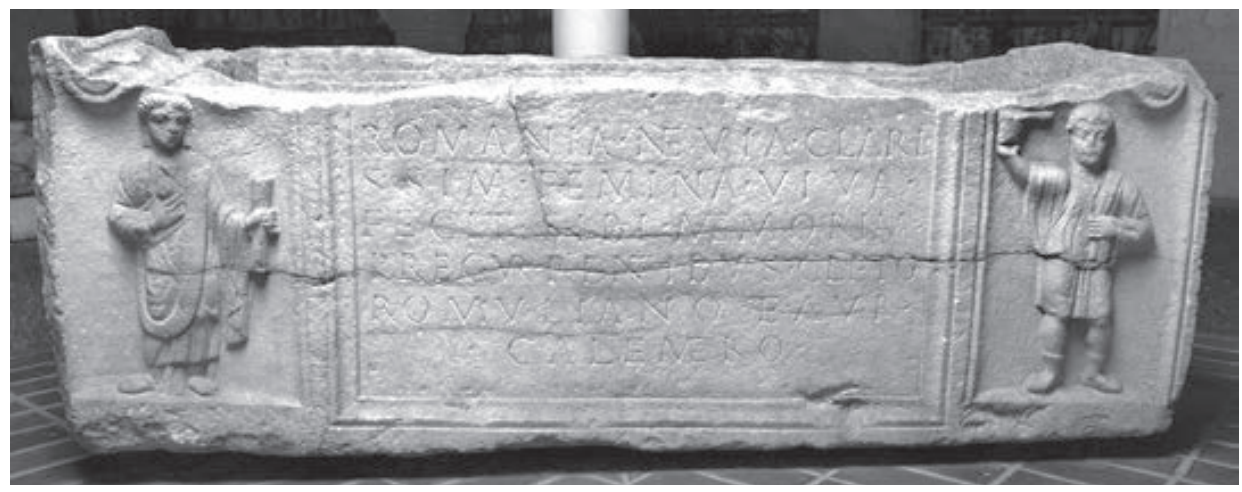

Sl. 4. Sarkofag Romanije Nevije (3. stoljeće), Sisak (Arheološki muzej u Zagrebu)

U nišama uz epitaf prikazana su dva reljefna stojeća lika. Na desnoj je strani mladić odjeven u opasanu tuniku s posudom u podignutoj desnoj ruci, dok ljevicom pridržava ručnik prebačen preko ramena. Na lijevoj je strani mlada žena odjevena u togu, koja u desnoj ruci drži okrugao plod, a u lijevoj veliki svitak (rotulus). Ta dva lika zajedno jedinstvena su inačica motiva slugu, koji je uobičajen na grobnim spomenicima Norika i Panonije, ali na

28 CIL III 10852; Branka Migotti, „Sarkofag Romanije Nevije iz Siska“, Godišnjak Gradskog muzeja Sisak, 2/2001., $37-88$.

29 S. R. Joshel, Slavery in the Roman World, 35-37; Christier Bruun, „Senators and Equites: Prosopography“, The Oxford Handbook of Roman Epigraphy (ur. Christer Bruun i Jonathan Edmondson), Oxford 2015., $202-222$. 
grobnim oltarima, a ne na sarkofazima. Jedinstvenost prizora na sarkofagu Romanije Nevije počiva na ženskom liku odjevenome u togu jer je taj odjevni predmet pripadao muškoj odjeći s konotacijama građanskog prava i društvenog statusa. Od žena, togu su nosile samo djevojčice prije pubertetske dobi, prostitutke, preljubnice i služavke. $S$ obzirom na posljednju kategoriju, prizor na sarkofagu Romanije Nevije ne bi trebao biti neuobičajen, ali on to ipak jest. Naime, podatak o služavkama odjevenima u togu zabilježen je u pisanim izvorima, ali je praktički nepoznat kao likovni motiv, pogotovo u grobnoj umjetnosti. $\mathrm{Na}$ grobnim spomenicima Norika i Panonije služavke su se prikazivale isključivo u jednostavnoj domaćoj haljini; togi ondje nema ni traga, kao ni svitku. ${ }^{30}$ Štoviše, u grobnoj umjetnosti Panonije čak se i muškarci rijetko prikazuju u togama, a žene se radije portretiraju u domaćoj negoli u rimskoj odjeći. Prema tome, morao je postojati vrlo poseban razlog da se na grobnom spomeniku jedna široko rasprostranjena slika sluge i služavke zamijeni neuobičajenim prizorom u kojemu se ističe prikaz žene u muškoj odjeći. Čini se da bi taj razlog trebalo tražiti u osobnosti Romanije Nevije, naslućenoj iz njezina epitafa unatoč nejasnoćama i dvojbama. Ako su ondje spomenuta dvojica ljudi uistinu bila njezini pokojni muževi, nekoliko pitanja ostaje neodgovoreno. Kako to da uz imena pokojnih muževa nisu bile navedene i odgovarajuće senatorske titule? One su mogle biti izostavljene nemarom ili namjerno, pod uvjetom da su ih ta dvojica uistinu i imala. Naime, žena iz senatorske obitelji mogla se udati za nekoga tko nije bio u njezinu statusu uz uvjet da je bio slobodno rođen rimski građanin, a ne oslobođenik, ali se na takve brakove ipak gledalo prijekim okom. ${ }^{31}$ Nadalje, zašto bi senatorska udovica uopće spominjala pokojne muževe na spomeniku u kojemu se namjeravala dati ukopati sama? I gdje su oni bili pokopani, ili barem drugi od te dvojice? Čini se da je siscijska clarissima femina bila toliko zaokupljena sama sobom i svojim društvenim položajem da joj nabrojena pitanja nisu bila važna.

Za razumijevanje moguće veze između duhovnog sklopa jedne Rimljanke i njezine pretpostavljene sklonosti nošenju muške odjeće treba se prisjetiti da su u rimskom društvu togu ponekad odjenuli ili se u njoj prikazali na spomenicima muškarci kojima društveni status to zapravo nije dopuštao jer nisu bili rimski građani. ${ }^{32}$ Možda je slična okolnost u podlozi djevojke u togi prikazane na sarkofagu senatorske gospođe iz Siska. Kao dvostruka udovica sa senatorskom titulom, možda je izabrala togu kao simbol nastojanja da pokaže posjedovanje muških vrijednosti i sposobnosti; ženska rodna mimikrija u (samo)predstavljanju u ukupnoj se povijesti ljudske civilizacije nastoji protumačiti upravo u takvom psihološkom okviru. ${ }^{33}$ Romanija Nevija mogla se nadati da će je iskazivanje muških vrlina i sposobnosti u društvenom životu Siscije staviti u položaj koji su uživali muškarci njezina statusa, a moguće i njezini muževi ako su kojim slučajem ipak bili senatori, dakle predodređeni za dužnosti senatorskog stupnja u upravnoj, sudbenoj, financijskoj i religijskoj sferi javnog života. ${ }^{34}$

30 B. Migotti, „Sarkofag Romanije Nevije iz Siska“, 73.

31 Simon Corcoran, The Empire of the Tetrarchs. Imperial Pronouncements and Government AD 284-324, Oxford 2000., 96-97; H. Mouritsen, The Freedmen in the Roman World, 297.

32 Usp. bilj. 6.

33 B. Migotti, „The Social/Gender Context of the Sarcophagus of a togata clarissima femina“, 70; S. Birk, Depicting the Dead, 115-117, 138.

34 Usp. S. R. Joshel, Slavery in the Roman World, 35-36; C. BRuUn, „Senators and Equites: Prosopography“, 201-219. 
Riječju, siscijska clarissima femina, jedina senatorska žena koja je ostavila traga u arheološkoj povijesti sjeverne Hrvatske, bila je po svemu sudeći jedinstvena samopouzdana osoba koja je uspjela nadići uobičajene društvene okvire u provinciji Panoniji u 3. stoljeću, dakle u prostoru i vremenu u kojima su gospodarile „muške“ vrijednosti i vrline.

\section{EPILOG}

Premda su epitafi u osnovi obiteljska i privatna stvar, njihov je širi društveni potencijal u rimskom razdoblju bio neporeciv jer su se obraćali prolazniku nudeći mu različite komponente (samo)predstavljanja pokojnika i očekujući od njega recepciju tog predstavljanja kao potvrdu uloge pokojnika u društvenom životu zajednice i kao jamstvo trajnog pamćenja. Kada se pjesnik i govornik Auzonije (Decimius Magnus Ausonius, 4. stoljeće) u pjesmi De nomine cuiusdam Lucii sculpto in marmore (Aus. Epit. 32) malodušno zapitao o tome treba li se čuditi što umiru ljudi, kad propadaju spomenici, a s njima i imena, samo je dijelom bio u pravu - mnogi su "preživjeli“ do danas. ${ }^{35}$

\section{$\cos$}

\section{Literatura}

Année épigraphique 2002., 1125.

Année épigraphique 2013., 1206.

Petronije Arbiter, Satirikon ili vragolaste pripovijesti (prir. Antun Branko Kalinić), Zagreb 1986.

Stine BIRK, Depicting the Dead. Self-Representation and Commemoration on Roman Sarcophagi with Portraits, Aarhus 2013.

Christier Bruun, „Senators and Equites: Prosopography“, The Oxford Handbook of Roman Epigraphy (ur. Christer Bruun i Jonathan Edmondson), Oxford 2015., 202-226.

Shane Butler (ur.), Deep Classics. Rethinking Classical Reception, London 2016.

Maureen Carroll, Spirits of the Dead. Roman Funerary Commemoration in Western Europe, Oxford 2006.

Simon Corcoran, The Empire of the Tetrarchs. Imperial Pronouncements and Government AD 284-324, Oxford 2000.

Corpus Inscriptionum Latinarum (CIL) III 3980, III 10852.

Jane Fejfer, Roman Portraits in Context, Berlin - New York 2008.

Augusto FraschetTI, „Introduction“, Roman Women (ur. Augusto Fraschetti), Chicago - London 2001., 1-21.

Hans Rupprecht Goette, Studien zu römischen Togadarstellungen, Mainz am Rhein 1989.

Henner von Hesberg, „Planung und Ausgestaltung der Nekropolen Roms im 2. Jh. n. Chr.“, Römische Gräberstrassen. Selbstdarstellung - Status - Standard (ur. Henner von Hesberg i Paul Zanker), München 1987., 43-60.

Sandra R. Joshel, Slavery in the Roman World, Cambridge 2010.

35 Shane Butler (ur.), Deep Classics. Rethinking Classical Reception, London 2016., 167-168. 
Guntram Косн - Hellmut Sichtermann, Römische Sarkophage, München 1982.

Richard Lim, „Theater“, Late Antiquity. A Guide to the Postclassical World (ur. Glen Warren Bowersock, Peter Brown i Oleg Grabar), Cambridge, MA - London 1999., 719-721.

Branka Migotтı, „Nadgrobni spomenik robovske obitelji iz Donjih Čeha kod Zagreba“, Archaeologia Adriatica, 2/2008., br. 2, 453-465.

Branka Migotтı, „Ranokršćanski grobni nalaz iz Velikih Bastaja kod Daruvara“, Vjesnik Arheološkog muzeja u Zagrebu, 28-29/1995. - 1996., 127-157.

Branka Migotтı, „Sarkofag Romanije Nevije iz Siska“, Godišnjak Gradskog muzeja Sisak, 2/2001., 37-88.

Branka Migotті, „The Social/Gender Context of the Sarcophagus of a togata clarissima femina from Siscia (Pannonia Superior)“, Archaeologia Bulgarica, 11/2007., br. 1, 61-79.

Richard Miles, „Actors and acting“, Late Antiquity. A Guide to the Postclassical World (ur. Glen Warren Bowersock, Peter Brown i Oleg Grabar), Cambridge, MA - London 1999., 276-277.

Henrik Mouritsen, The Freedmen in the Roman World, Cambridge 2015.

Jacopo OrTALli, „Simbolo e ornato nei monumenti sepolcrali romani: il caso aquileiese“, Aquileia dalle origini alla costituzione del ducato longobardo. Topografia, urbanistica, edilizia pubblica (ur. Giuseppe Cuscito i Monika Verzár Bass), Trieste 2004., 245-286.

Costas Panayotakis, Theatrum Arbitri. Theatrical Elemets in the Satyrica of Petronius, Leiden 1995.

Nicholas Purcell, „Tomb and Suburb“, Römische Gräberstrassen. Selbstdarstellung - Status - Standard (ur. Henner von Hesberg i Paul Zanker), München 1987., 25-41.

Ante Rendić-Miočević, „The Marble Funerary Stele of the Cohors II Varcianorum Equitata's Veteran, Titus Flavius Ateboduus from the Odra Village near Zagreb“, Sepulkralna skulptura zapadnog Ilirika i susjednih oblasti u doba Rimskog Carstva (ur. Nenad Cambi i Guntram Koch), Split 2013., 343-381.

Shelly Stone, „The Toga: From National to Ceremonial Costume“, The World of Roman Costume (ur. Judith Lynn Sebesta i Larisa Bonfante), Madison - London 1994., 13-45.

Geoffrey Sumi, „Impersonating the Dead: Mimes at Roman Funerals“, The American Journal of Philology, 123/2002., br. 4, 559-585.

Marjeta ŠAšEL Kos, „Centenarians in the Emona area and the adjacent Norican and Pannonian regions“, Misurare il tempo, misurare lo spazio (ur. Maria Gabriella Angeli Bertinelli i Angela Donati), Faenza 2006., 175-197.

Jocelyn M. C. Toynbee, Death and Burial in the Roman World, Baltimore - London, 1996.

Giusto Traina, „Lycoris the mime“, Roman Women (ur. Augusto Fraschetti), Chicago - London 2001., 82-99.

Robert Turcan, The Cults of the Roman Empire, Oxford - Cambridge, MA 1996.

Cinzia Vismara, „L'apport des textes antiques“, Incinérations et inhumations dans l'Occident romain aux trois premiers siècles de notre ère (ur. Michel Vidal), Toulouse I992., I07-I47. 


\section{$\cos$}

\section{Funerary monuments from Northwestern Croatia IN LIGHT OF THE ATTITUDE TOWARDS DEATH IN THE ROMAN ANTIQUITY}

Roman law defined the grave as a sacred place (locus religiosus), protected from any kind of sacrilege and subject to legally bound maintenance by the heirs, who were also obliged to conduct the prescribed ritual performances. Because oblivion was considered to be the starkest form of death, the Romans were obsessed with the preservation of eternal memory as the guarantee of life beyond the grave, regardless of how vague their ideas of such a life and its imagined locations might have been. In such circumstances, the funerary monument was the most important material aspect of the preservation of memory, through which the heirs conveyed information about their dead ancestors to the living. Roman epitaphs, which range from lapidary phrases with basic information about the deceased and the bereaved, to lengthy poems with literary ambitions and psychological-philosophical aspirations, contain a wide range of information concerning the social standing, material wealth, and religious preoccupations of the inhabitants of the Empire. However, the greatest of the "speakers" and the most trustworthy of memory-keepers were the stones that featured epitaphs and portraits of the deceased, accompanied by various other symbolic images. Nevertheless, the mental images of the past as displayed on funerary stones need to be interpreted cautiously, always bearing in mind that the epitaphs tended towards careful pre-selection, naturally highlighting those particular attributes most favourable to the deceased. The above-mentioned commonplaces of Roman funerary anthropology are illustrated in this paper through four funerary monuments from the Northwest of Croatia, two each from Roman Andautonia (Ščitarjevo near Zagreb) and Siscia (Sisak). The first two provide insight into the social context of the life and death of an indigenous auxiliary soldier called Titus Flavius Ateboduus, who became a Roman army veteran, and that of a well-to-do slave family. The other two belonged to a centenarian called Leburna, the head and owner of a mimic troupe, and a senatorial lady called Romania Naevia, who seems to have risen above the usual female social standing defined by male domination, as suggested by the image of a woman dressed in a typical male garment - toga, which is shown on her sarcophagus.

Key words: the Roman civilization, death, epitaph, funerary monuments, Sisak (Siscia), Ščitarjevo (Andautonia) 
